gressionally-mandated assignments',

The GAO is the investigative arm of Congress, and the report, published in Washington last week, was commissioned by Senator Adlai Stevenson, chairman of the Senate Commerce Committee's science, technology and space subcommittee. The GAO was asked to comment on how well OSTP was carrying out the legislative mandate that had been placed on it. OSTP was reestablished by Congress in 1976 after having been disbanded by President Nixon four years earlier.

The general conclusion of the GAO report is that OSTP has operated effectively in many areas. But by seeking primarily to influence decision-making within the existing policy frameworks laid down by the White House, it has failed to provide sufficient independent leadership, as envisaged in the legislation, in laying out a broad national strategy for science and technology.

Dr Frank Press, director of OSTP and the President's Science Advisor, denies that his office has failed to fulfil its mandate. In a letter to the GAO he disputes the various charges made in the GAO report and claims that dealing with strategic planning issues through particular topics and areas has been the most sensible approach.

Two particular aspects of OSTP's activities were singled out by $\mathrm{Mr}$ Stevenson for the GAO's attention. The first was the question of how far OSTP had studied various issues related to the federal organization and management of science and technology policy listed explicitly in the 1976 Act.

Here the report says that many of OSTP's actions have addressed the issues defined, some extensively, such as interactions with the Office of Management and Budget over budget decisions, and relationships with other federal agencies such as the National Science Foundation.

It also points out specific requirements which have not been met, such as the provision of a regular report to Congress on the state of science and technology. The GAO quotes the opinion of OSTP staff that broad, comprehensive reports are less useful than reports and actions addressing specific current problems.

However, it is in response to $\mathrm{Mr}$ Stevenson's second question that the GAO makes it most critical comments and OSTP has reacted most sharply. This is the extent to which OSTP has been involved in strategic planning for US science and technology, and the constraints under which such planning has been conducted.

As GAO admits, the concept of strategic planning is difficult to define in the context of the decentralized and pluralistic market economy of the United States. But two ways in which science and technology are important to planning efforts are identified, first in their intrinsic role in almost all policy issues and second in their increasing importance to society in their own right.

The GAO says that although OSTP staff attempt to give strategic perspective to considerations of topical or "mission" issues, such as energy or space, they believe that it is not feasible to do more comprehensive strategic planning while remaining effective within the Office of the President. OSTP therefore seldom studies the relationships of issues in the whole context of science and technology, the report says.

It characterizes this as largely a question of operating style. OSTP staff, says the GAO, "see themselves as an active agent of change within the system", and feel that the office as a whole must respect the norms of the system, an attitude which the GAO says directly affects their ability to generate new issues or advocate change.

OSTP officials defend this strategy. They point out, for example, that apart from the advice offered on specific issues such as the reorganization of energy research or budget support for basic science, OSTP does not have any independent control over the policy-making process. And efforts at painting broadbrush policies might produce little result.

In his letter to the GAO, Dr Press comments that OSTP has taken what he calls a "sensible" course in its approach to strategic issues and that "we do not believe that our effort to focus policy development has been constraining. Rather it has enabled us to address policy issues on a manageable basis".

He also reacts to the GAO's complaint that OSTP has no formal mechanism for establishing a broad agenda for itself by replying that this could be limited by the need for confidentiality at critical junctures in the policy process, and that "no one group is likely to have the breadth of view to encompass the ever-increasing span of science and technology".

The charges made in the GAO report have been made in more piecemeal fashion from other directions in the past. OSTP has tended to dismiss many of these criticisms as reflecting a misinterpretation of the complexity of its role, and a lack of recognition of the constraints under which it has to operate.

In the short term the GAO report is not likely to have much effect. With less than four months of the current administration left, there is little pressure from the White House or OSTP for a change in policy; and Dr Press has made it clear that he is unlikely to stay on for another term.

More significant will be the role of the report in discussions over Dr Press's successor. Several members of Congress who have previously expressed similar conclusions - and are likely to do so again at a Senate hearing on the report, scheduled to take place on Friday - feel that this may be the most effective way to make their opinions felt.

David Dickson

\section{Smallpox inquiry Union in dispute}

The repercussions of the smallpox accident at the Department of Medical Microbiology of the University of Birmingham, which led in 1978 to the death of Mrs Janet Parker, a technician in the department, were revived last week by the Association of Technical and Managerial Staffs (ASTMS). The union, which had been hoping to give evidence at the postponed inquest on Mrs Parker's death, due to reopen on Monday this week, has criticized the quality of the scientific evidence given at the earlier court case in which the University of Birmingham successfully defended itself against a prosecution brought by the Health and Safety Executive. The jury at the inquest gave a verdict of death by misadventure, rejecting the alternative of criminal negligence.

The ASTMS argument centres largely around the evidence given at the court proceedings by Professor Kevin McCarthy of the University of Liverpool, called by the University of Birmingham as an expert witness. His evidence was relevant because the official inquiry into the affair, conducted by a committee under Professor R.A. Shooter, concluded that Mrs Parker was most likely to have been infected with smallpox as a result of airborne transmission of the virus or, alternatively, by personal contact.

The import of McCarthy's evidence was that the procedures used in the smallpox laboratory at Birmingham were unlikely to have led to the production of aerosol contamination. To this end, he told the magistrates' court, he had himself carried out a series of experiments to assess the risk of aerosol production by procedures used in the smallpox laboratory. One of these involved the use of a water pump for actuating a pipette used for withdrawing supernatant fluid from Petri dishes in which smallpox virus had been cultivated. The pump was separated from the pipette by two flasks containing formalin.

Professor McCarthy's simulation of this equipment used the bacterium Escherichia coli rather than virus particles. On the basis of his results, he calculated that the chance of smallpox virus escaping in aerosol form would have been so small that one particle would get out once in 2,000 years.

ASTMS takes Professor McCarthy to task on the grounds that the simulation was not realistic. In practice, the ASTMS report says, the pipette would have been withdrawn from Petri dishes at frequent intervals, during which aerosol particles would be carried into the stream of water in the water pump and released into the laboratory by splashing.

The ASTMS document says that Professor McCarthy's evidence "tells us little except that he is a reasonably competent tchnician but does not really 
understand the hazard"'. The document also criticizes as unwarranted Professor McCarthy's inferences about the production of aerosol particles carrying virus from safety cabinets used in the smallpox laboratory.

Those questioned earlier this week about the ASTMS allegations were unwilling to comment without an opportunity to study the text. Those witnesses at the court hearing who were reached by telephone said, however, that they stood by their evidence.

The coroner at the inquest on Mrs Parker's death had let it be known in advance that he did not wish to go over ground already covered at the court hearing. $\mathrm{Mr}$ Clive Jenkins, General Secretary of ASTMS, has nevertheless written to him with a copy of the document. He has also written to $\mathrm{Dr}$ Gerald Vaughan, Minister of Health, demanding that the Dangerous Pathogens Advisory Group be reconstituted by including public interest and trades union representatives, and that the government should make clear that it is prepared to spend the monies necessary to make laboratories in universities and hospital pathology departments safe.

\section{Law of the Sea}

\section{Hurdles to jump}

\section{Washington}

Final agreement on international legislation covering deep-sea mining could prove more elusive than suggested by the successful completion of negotiations on a draft United Nations Law of the Sea Treaty in Geneva last month. Even if - as indeed seems likely - a draft treaty is finally agreed and signed by member nations after a final meeting in Caracas early next year, there remains the question of ratification, required of at least sixty states. And this could prove a major stumbling block, particularly in the US Senate.

Member companies and trade associations of the American Mining Congress (AMC) are meeting in San Francisco next weekend to decide their position on the draft treaty which emerged from the Geneva negotiations, the culmination of more than twenty years of talks.

Prior to the Geneva meeting, the congress had expressed strong reservations about some aspects of the US negotiating position, claiming that the chief US negotiator, Ambassador Elliott Richardson, was giving away too much in his eagerness to get the treaty signed.

Many of the companies still express the same reservations. And the AMC's views could be crucial in determining whether the US Congress decides to back the treaty. Earlier this year, following strong pressure from the mining companies, Congress passed a unilateral law defining conditions under which US companies could engage experimentally in deep-sea mining from
1981 unless the UN treaty is in force. Similar actions by Germany, and proposed actions by the United Kingdom and France, are among the factors said to have precipitated the Geneva agreement.

The stakes are high. Total investments of more than $\$ 1,000$ million are expected to be made by each of the four major consortia now preparing to engage in deep-sea mining, primarily for manganese nodules containing nickel, cobalt and copper. The companies are demanding, above all, a degree of certainty about a reasonable return on their investment.

Among the areas that the mining companies are unhappy about are:

- The lack of guaranteed representation of the United States on the 37-member council of the International Seabed Authority, even though the Soviet Union is given three seats, a position which one executive predicted that the Senate would find difficult to accept.

- The participation as signatories of the treaty of organizations other than UN member states, such as the Palestine Liberation Organization. This could entitle such organizations to share in the profits of deep-sea mining which the US companies are required to provide to the authority for distribution as development aid.

- The requirement that mining companies should make their mining technology available to other countries who demand it.

The major question now facing both US and UN negotiators is whether any movement is possible on these issues before the treaty is signed next year and, if not, whether they are likely to provide a sufficient obstacle to prevent Senate ratification, given the many other advantages to the United States in an international treaty that covers all aspects of nations' rights to the oceans.

None of these reservations is, in itself, expected to be a major stumbling block to the final treaty. Nor, among those who are strong supporters of the treaty, is there any desire to open up discussion again in case the whole package begins to unravel. But claims that "it is all over bar the shouting" may turn out to be a little premature.

David Dickson

\section{Overseas students}

\section{Some win, some lose}

British universities and colleges appeas to differ markedly in their expectations of numbers of overseas students in the coming academic year. Some universities - a litte to their surprise - expect there will be very little change between last year and this in the numbers of students from overseas. Others expect that numbers will be, by contrast, substantially reduced.

The issue has become a lively topic of conversation among academic registrars because the coming academic year is the first in which the steep increases of student fees decreed by the British government a year ago will begin to bite. The fees apply only to new students, or to students embarking on new courses. Registrars are also quick to point out that at this stage in the academic year, before students have actually registered and paid their fees, estimates of how many will turn up are bound to be provisional.

The universities where there appears to have been very little change in the demand for places include the University of Salford and Loughborough University of Technology. At both institutions (as at most universities) overseas students are now required to produce not merely their fees but a financial guarantee from a bank or some scholarship awarding body, which may require that a student should have $£ 6,500$ at his disposal in each of three consecutive academic years.

Elsewhere, the preliminary figures suggest that some kinds of courses are likely to suffer more than others. Applications for places on MSc courses appear to be comparable with last year's at some institutions, which are nevertheless guessing that overseas students will be reduced by ten per cent or more in undergraduate and $\mathrm{PhD}$ courses.

One of the difficulties of estimation is that students who have nominally accepted places fail to turn up by the beginning of term, for most British universities early in October. In normal years, it is expected that overseas students will apply to several universities but in the end accept a place at only one of them, which means that a certain amount of double counting is unavoidable at this stage in the academic year. But some also fail to turn up for reasons which are never explained. Some registrars fear that difficulties over finance may increase the numbers in this category in the coming year.

With all these reservations, Imperial College, London says that there has been a "discernible" reduction of the numbers of completed applications from overseas. Portsmouth Polytechnic, one of the largest institutions of higher education in the United Kingdom, is similarly affected and wonders ruefully whether the explanation may not be the rules which require polytechnics to charge fees laid down by the Department of Education and Science. This year, polytechnic fees for overseas students are nominally some $£ 300$ to $£ 400$ greater than those in universities.

While registrars at all kinds of institutions agree that the present period is more confusing than any other within living memory, most of them appear to be mildly encouraged that the decline in numbers has not been as dramatic as some of them were fearing earlier this year. Unless there is a sharp deterioration in the next few weeks, overseas student numbers are unlikely to be reduced by anything like the 50 per cent feared by some or by the 30 per cent which appears to have been the base-line for financial planning for the coming year. 